\title{
Editorial water history issue 3/4 2019
}

\author{
Maurits W. Ertsen ${ }^{1} \cdot$ Ellen F. Arnold ${ }^{2}$
}

Published online: 20 November 2019

(c) Springer Nature B.V. 2019

In this last (combined) issue of 2019, we find six close encounters between human populations and water. Water supply is an important focus of many of the papers in this issue, which take on questions about the quantity, quality, and availability of water supplies in urban areas. They also address how as is the human imagination matters for water systems and water governance.

The combination of the two is discussed in the first paper, which explores the introduction of a water supply system in Trivandrum, India in the late nineteenth and early twentieth century. The paper argues that the British colonial engineers aimed to replicate systems adopted in London and Paris, and that this focus on replicating this ideal helps explain inequitable access to water in urban areas in India.

We continue on the theme of urban water supply in the second paper, which introduces us to Naples's water supply in Italy between 1500 and 1750. Naples relied on an underground network of reservoirs, cisterns, channels and conduits, fed by an ancient aqueduct. Through details on water quantity and water quality, the paper criticizes the widespread views of early modern Naples as "chaotic", arguing instead that the system showed remarkable resilience and ingenuity.

The third paper discusses water quality in the Illinois River (USA) between 1865 and 1910. Many cities along the Illinois River realized that the Chicago Sanitary and Ship Canal, completed in 1900 to carry Chicago's wastes downstream and promote shipping, would affect the water quality of the river. At the same time, many promoted opportunities to increase fish catches and expand commercial opportunities too.

The fourth paper discusses the qanat of Hassan Abad (Iran) in the last century and explains how the qanat and its properties relate to the development of a cooperative water management system between the settlements along the canal. This is another paper in our recent series on qanat technology, that aims to bring new insights on this old technology and to counteract many of the continuous (if not accurate) ideas on the technology.

The fifth paper takes up another enduring story, this time related to Dutch water management, on the tale of the boy who would have prevented flooding by putting his finger in a hole of an embankment in the Netherlands. This story is well known all over the world and keeps being used as example of ingenious Dutch water management. By discussing

Maurits W. Ertsen

M.W.Ertsen@tudelft.nl

1 TU Delft, Delft, The Netherlands

2 Ohio Wesleyan University, Delaware, USA 
how and in what variations the story has been retold, the paper complicates this simple narrative.

Our final paper provides another important focus in water studies, by studying the functioning of the historical aqueduct of Kavala, founded as Neapolis in seventh century B.C. Greece. Its aqueduct carried water to the city. The paper discusses evidence to suggest that its construction dates from the late Roman era, but that it was reconstructed in the Ottoman period in the sixteenth century AD. Finally, new evidence suggests that the discharge was quite large in relation to the population that it was supposed to serve, but that the water could not reach the entire city area. As such, imaginative as the aqueduct may have been, it could not supply the entire population with the water it brought.

Together, these article remind us of the technical, hydrological, social, and cultural factors that combine to create both water infrastructure and historical narratives about that infrastructure. Governments, engineers, and children's book authors all tell stories about the water that surrounds them, and all work to intervene, at different scales, in how people access and understand water.

Publisher's Note Springer Nature remains neutral with regard to jurisdictional claims in published maps and institutional affiliations. 